Research Article

\title{
Factor Affecting Wheat Seed Production and Associated Constraints in Kailali District, Nepal
}

\author{
Pratibha Bist $^{1 *}$, Prashant Bhatt ${ }^{1}$, Naresh Singh Bist ${ }^{1}$, Rojina Kafle ${ }^{1}$ \\ ${ }^{1}$ Agriculture and Forestry University (AFU), Rampur, Nepal
}

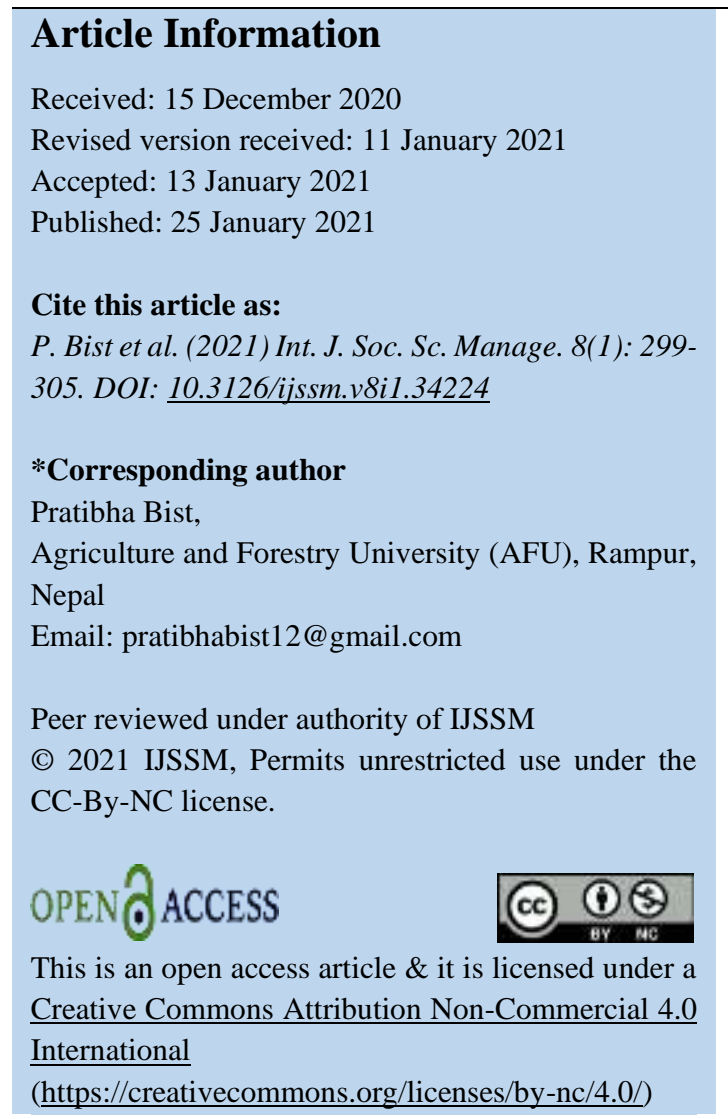

Keywords: Market; Input; Services; Seed System

\begin{abstract}
A seed is the most important input to increase wheat production. A seed is the biological basis of the world food security and, directly or indirectly supports the livelihood of every person on earth. To improve the productivity of wheat seed, it is important to adopt improved seed production technologies. Thus, the presented study was conducted with help of a well-structured questionnaire to assess the socio-demographic characteristics, economic status of producers, land \&livestock holding, access to different agricultural services, drivers of seed production, market status and marketing of wheat seed, availability of different inputs, and constraints faced by seed producers during production as well as marketing. 60 formal and informal wheat seed producers were included in the survey. It was observed that the majority of wheat seed producers lacked services such as field inspection, roguing, cleaning, and processing. So, they do not acquire the best possible return from seed production. The number of middlemen involved in marketing of wheat seed is high, thus reducing price received by the farmers for their product. Due to lack of quality input, erratic rainfall, lack of technical support, lack of access to the market, the wheat seed production has not been carried out at its full potential in the study region.
\end{abstract}

\section{Introduction}

Wheat (Triticum aestivum) is the world's most widely cultivated food crop and is cultivated in most parts of the world. The productivity of wheat in Nepal is very low as compared to other developed countries which may be due to shortage of production inputs, inadequate pest disease management, inadequate infrastructure and mechanization, less and unbalanced use of plant nutrients etc, the use of other inputs such as fertilizer, irrigation, plant protection only, does not yield good economic return without the use of quality seed (Thapa, 2005). Wheat seed production requires more technical knowledge and superior crop management practices than that for the grain production. To meet the demand of farmers, around 16,325 tonne quality wheat seed production is necessary (NSB, 2013). When a part of the production is damaged /affected by disease pest, it should be replaced by seeds produced in other plots; otherwise, the farmers will not be able to rely on the producers for stable supply (JICA, 2017). This may be quite 
difficult and uneconomic for a single farmer to manage; thus, seed production by seed production cooperatives is encouraged.

The use of inputs in wheat depends largely on availability of irrigation facilities and working capital with the farmers for acquiring the purchased inputs. As the small and marginal farmers have inadequate capital base, nonavailability of adequate credit may be a problem in exploring the production potential by them (Heena, 2016). But the changing marketing conditions, rapidly increasing input price, delay in transfer of technology to farmers' field, decline in size of holding, poor storage and processing facilities, higher transportation charge increases the cost of wheat seed production. Large number of market middleman and inaccurate marketing practices lower the producers' share in consumers' rupee. The factors affecting wheat productivity are the average of tenants' age, family labor, distance from home to field, hired labor, the distance of farm to the source of irrigation, number of irrigations, the term of irrigation. Furthermore, the major constraints of wheat production normally regard as a cost issue and lack of awareness wheat grower, especially about the wheat technical package (Elgilany, Sulaiman, \& Mohd, 2011).

\section{Objectives}

- To study the socio-demography of wheat seed producers.

- To study factors related to wheat seed production and marketing.

- To study major constraints of wheat seed production in the study area.

\section{Materials and Methods}

\section{Study Area and Sampling}

Kailali District is one of the 77 districts of Nepal which lies between 28.826688 to 28.614941 latitude and 80.513178 to 81.233567 longitudes. The district lies in the Terai plain of Sudurpaschim province. The district, with Dhangadhi as its district headquarters, covers an area of 3,235 square kilometers (1,249 sq mi) and has a population of 775,709 (616,697 in 2001 census) (NPHC, 2011). The study area includes Ghodaghodi Municipality, Gauriganga
Municipality, and Kailari Rural Municipality. 60 wheat seed producers were randomly and purposefully selected for the study from which 30 were formal wheat seed producers and 30 were informal wheat seed producers. The formal seed producers are organized farmers following formal seed production system i.e. deliberately constructed system that involves a chain of activities with guiding principle to maintain varietal identity and purity and to produce seed of optimal physical, physiological and sanitary quality. The informal system, also referred to as a local seed system, is based on farmer-saved seed and farmers following such system are informal seed producers (Nickerson, 2020). The survey was initiated in June 2020.

In order to achieve third objective five-point Likert scale method was used to analyze constraints in wheat seed production. Farmers were asked to rank problems according to their preference, then rank of each problem was converted into preference points; rank $1=5$, rank $2=4$, rank $3=3$, rank $4=2$ and $\operatorname{rank} 5=1$.

Relative Importance Index $(\mathrm{RII})=\sum$ (Preference point $\times$ no. of times preferred)/Highest Preference point*no of total observations

\section{Result and Discussion}

\section{Socio-Demographic Characteristics}

Socio-demographic characteristics of wheat seed producers are presented in Table $1 \& 2$. The average size of households for formal seed producers (6.9) was not significantly higher than that of informal seed producers (5.7). The number of female family members was lower than the number of male members in both cases. The average dependency ratio was not significantly higher in formal seed-producing households $(96.2 \%)$ than informal $(81.2 \%)$. Average no. of male members, female member, economically active and dependent members are given in Table 1.

Among sampled households $78.3 \%$ households had male household head, while other $21.7 \%$ had female household head. Table 2 shows gender and education level of household head for formal and informal seed production system.

Table 1: Socio-demographic characteristics of wheat seed producers

\begin{tabular}{llll}
\hline Variables & Overall & Formal system & Informal system \\
\hline Age of household head & 42.5 & 40.3 & 44.7 \\
Female member & 3.1 & 3.4 & 2.7 \\
male member & 3.2 & 3.4 & 3.0 \\
Economically active members & 3.5 & 3.7 & 3.27 \\
Dependent member & 2.8 & 3.2 & 2.4 \\
Total members & 6.3 & 6.9 & 5.7 \\
Dependency ratio & $88.6 \%$ & $96.2 \%$ & $81.2 \%$ \\
\hline Source: Field survey 2020 & &
\end{tabular}


Table 2: Socio-demographic characteristics of wheat seed producers

\begin{tabular}{llll}
\hline Variable & Overall & Formal System & Inform \\
\hline Gender of Household Head & & & \\
Male & $78.3 \%$ & $80.0 \%$ & $76.7 \%$ \\
Female & $21.7 \%$ & $20.0 \%$ & $23.3 \%$ \\
Education level & & & \\
Illiterate & $25.0 \%$ & $16.7 \%$ & $33.3 \%$ \\
literate & $21.7 \%$ & $20.0 \%$ & $23.3 \%$ \\
Primary level & $8.3 \%$ & $10.0 \%$ & $6.7 \%$ \\
Lower secondary level & $20.0 \%$ & $33.3 \%$ & $6.7 \%$ \\
Secondary level & $20.0 \%$ & $13.3 \%$ & $26.7 \%$ \\
Higher studies & $5.0 \%$ & $6.7 \%$ & $3.3 \%$
\end{tabular}

Source: Field Survey 2020

While analyzing education level of seed producers, percentage of illiterate was highest $(33.33 \%)$ following by secondary level education $(26.7 \%)$ and literate $(23.3 \%)$ in case of informal system. No. of seed producers with lower secondary level education (33.3\%) and literate (20\%) was found higher in formal seed producers. Similarly, only $3.3 \%$ of producers from informal had higher studies.

\section{Occupation}

Majority of sample households' main occupation was agriculture. $93.3 \%$ household from formal seed producers and $90.0 \%$ households from informal seed producer had agriculture as their main occupation. Trade was found to be main occupation for $3.3 \%$ of formal and $3.3 \%$ of informal seed producing households. Percentage of informal seed producing households with daily wage and service as their main occupation was $3.3 \%$ for each.

\section{Remittance}

Among formal seed producing household, 3 members from two families were abroad. Their average annual remittance was found to be NRs. 11,50,000. Similarly, 2 family members from 2 informal seed producer household were abroad. Their average annual remittance was found to be NRs. 9,00,000. There was no contribution of remittance in income of almost all household.

\section{Annual Income and Expenditure}

Average annual income of formal and informal seed producers was similar which might be because most of the households from both groups (more than 90\%) have agriculture as their main occupation. The average annual saving of formal seed producers was found to be NRs.
$1,66,100$ whereas that of informal seed producers was found to be NRs. 70833.3 which was not significantly different.

Table 3: average annual income and expenditure of wheat seed producers

\begin{tabular}{lll}
\hline $\begin{array}{l}\text { Seed production } \\
\text { System }\end{array}$ & $\begin{array}{l}\text { Average annual } \\
\text { income (NRs.) }\end{array}$ & $\begin{array}{l}\text { Average annual } \\
\text { expenses (NRs.) }\end{array}$ \\
\hline Formal system & $3,54,166.7$ & $1,88,066.7$ \\
Informal system & 256500.0 & $1,85,666.7$ \\
Source: Field survey 2020 & \\
\hline
\end{tabular}

\section{Land Holding}

Average land holding of sampled farmers is given in Table 4. Total owned land area was found significantly higher for formal seed producers. Since higher portion of families $(73.3 \%)$ were joint family among formal seed producers which was lesser among informal ones (46.7\%), level of land fragmentation would be higher in informal seed producers. This might have resulted in significantly higher land holding of formal seed producers than informal seed producers.

\section{Access to Agricultural Services}

$80 \%$ of the formal seed producers were found to have access to extension services, while only $46.7 \%$ of informal seed producers had access to extension services. Similar $80 \%$ of the seed producers had access to credit services. All of the farmers were involved in agricultural cooperatives and most of them were following irrigated farming system (Table 5).

Private companies provided information about product price, government provided information about new technologies and methods to the all wheat-seed producers provided with technical support. Similarly, government also 
provided information about how to use and maintain input factors such as equipments. None of the producers had information about seed processing methods nor did they carry out processing. Similarly, field inspection and roguing were not carried out.

\section{Driver of Seed Production}

The main reason behind seed production for formal seed producers was found to be technical backup from different organization while that for informal was higher income. Prime Minister Agriculture Modernization Project, Wheat Superzone, Kailali had provided $50 \%$ subsidy on seed and herbicide for formal wheat seed producers. Market price of wheat seed is higher than that of wheat grain (Table 6).

Table 4: Land and livestock holding of wheat seed producers

\begin{tabular}{llll}
\hline Types of land & Overall & Formal system & Informal system \\
\hline Irrigated owned land (kathha) & 27.2 & 33.3 & 21.2 \\
Unirrigated owned land (kathha) & 15.3 & 0 & 15.3 \\
\hline Total owned land (kathha) & 27.9 & 33.3 & 22.7 \\
\hline Unirrigated agricultural land (kathha) & 13.6 & 0 & 13.7 \\
Irrigated agricultural land (kathha) & 24.0 & 29.9 & 18.2 \\
\hline Total agricultural land (kathha) & 24.7 & 29.9 & 19.6 \\
\hline Leased in (kathha) & 12.5 & 15.1 & 9.9 \\
Leased out (kathha) & 13.5 & 0 & 13.5 \\
Irrigated wheat area (kathha) & 20.4 & 25.5 & 15.0 \\
Unirrigated wheat area (kathha) & 14.0 & 0 & 14.0 \\
\hline Total wheat cultivated area (kathha) & 20.5 & 25.5 & 15.4 \\
\hline Total livestock unit & 4.6 & 4.7 & 4.6 \\
\hline Source: find survey 2020 & & &
\end{tabular}

Source: field survey 2020

Table 5: Access to services of wheat seed producers

\begin{tabular}{|c|c|c|c|}
\hline Variable & Overall & Formal system & Informal system \\
\hline \multicolumn{4}{|c|}{ Irrigation facility } \\
\hline Yes & $91.6 \%$ & $100 \%$ & $83.3 \%$ \\
\hline No & $8.4 \%$ & $0 \%$ & $16.7 \%$ \\
\hline \multicolumn{4}{|c|}{ Involvement in agriculture cooperative } \\
\hline Yes & $100 \%$ & $100 \%$ & $100 \%$ \\
\hline No & $0 \%$ & $0 \%$ & $0 \%$ \\
\hline \multicolumn{4}{|c|}{ Access to extension services } \\
\hline Yes & $63.3 \%$ & $80.0 \%$ & $46.7 \%$ \\
\hline No & $36.7 \%$ & $20.0 \%$ & $53.3 \%$ \\
\hline \multicolumn{4}{|c|}{ Access to credit services } \\
\hline Yes & $80.0 \%$ & $86.7 \%$ & $73.3 \%$ \\
\hline No & $20.0 \%$ & $13.3 \%$ & $26.7 \%$ \\
\hline \multicolumn{4}{|c|}{ Access to technical support } \\
\hline Yes & $56.14 \%$ & $73.33 \%$ & $37.04 \%$ \\
\hline No & $43.86 \%$ & $26.67 \%$ & $62.96 \%$ \\
\hline
\end{tabular}

Source: Field Survey 2020

Table 6: Drivers of wheat seed production

\begin{tabular}{llll}
\hline Reasons for seed production & Overall & Formal system & Informal system \\
\hline Following the tradition & $11.7 \%$ & $0 \%$ & $23.3 \%$ \\
Easier & $13.3 \%$ & $6.7 \%$ & $20.0 \%$ \\
Higher Income & $43.3 \%$ & $30.0 \%$ & $6.7 \%$ \\
Increasing market access & $1.7 \%$ & $3.3 \%$ & $0 \%$ \\
Technical backup & $30.0 \%$ & $60.0 \%$ & $0 \%$ \\
Source: Field survey 2020 & & &
\end{tabular}


Farmers used improved wheat seed for the seed production process. Urea, DAP and potash were used as chemical fertilizers. Most of the seed producers used FYM prepared by them. Only small proportion of producers used herbicide which was provided by the PMAMP. Gunny bag and plastic sacks were majorly used as plastic material, which is provided by seed buyers (Table 7).

\section{Wheat Seed Marketing}

Most of the seed produced was supplied to local market. Wheat Superzone, Kailali provided aid to the formal wheat seed producer for seed marketing (Table 8).

Marketing of wheat seed was found to be done by five different marketing channels, shown in the box 1.

Table 7: Input supplier for wheat seed production

\begin{tabular}{lllll}
\hline Source & Seed & Fertilizer & Manure & $\begin{array}{l}\text { Packing } \\
\text { material }\end{array}$ \\
\hline Formal wheat seed production & & & \\
Self & $3.33 \%$ & $0 \%$ & $85 \%$ & $3.3 \%$ \\
Cooperative & $0 \%$ & $86.7 \%$ & $5 \%$ & $16.7 \%$ \\
PMAMP & $93.33 \%$ & $0 \%$ & $0 \%$ & $0 \%$ \\
Private & $3.33 \%$ & $13.3 \%$ & $5 \%$ & $80 \%$ \\
Informal wheat seed production & $6.67 \%$ & $0 \%$ & & \\
Self & $70 \%$ & $71.43 \%$ & $11.11 \%$ & $83.33 \%$ \\
Cooperative & $13.33 \%$ & $0 \%$ & $0 \%$ & $4.17 \%$ \\
PMAMP & $10 \%$ & $28.57 \%$ & $5.56 \%$ & $54.17 \%$ \\
Private & & &
\end{tabular}

Source: Field survey 2020

Table 8: Wheat seed marketing

\begin{tabular}{clll}
\hline \multicolumn{1}{c}{ Variable } & Overall & Formal system & Informal system \\
\hline Mode & & & \\
Contract & $12.24 \%$ & $13.33 \%$ & $10.53 \%$ \\
$\quad$ Non contract & $87.76 \%$ & $86.67 \%$ & $89.47 \%$ \\
Buyer & & & \\
$\quad$ Wholesaler & $2.04 \%$ & $3.33 \%$ & $0 \%$ \\
$\quad$ Collector & $36.73 \%$ & $46.67 \%$ & $21.05 \%$ \\
$\quad$ Local trader & $61.22 \%$ & $50 \%$ & $78.95 \%$ \\
End market & & & \\
$\quad$ Local market & $69.39 \%$ & $56.67 \%$ & $89.47 \%$ \\
$\quad$ Distant market & $30.61 \%$ & $43.33 \%$ & $10.53 \%$ \\
\hline Source: Field survey 2020 & & &
\end{tabular}

\section{Box: 1}

Channel I: $\quad$ Farmers $\rightarrow$ Pre-harvest Contractor $\rightarrow$ Wholesalers $\rightarrow$ Retailers $\rightarrow$ Consumer

Channel II: Farmers $\rightarrow$ Wholesalers $\rightarrow$ Retailers $\rightarrow$ Consumer

Channel III: Farmers $\rightarrow$ Collector $\rightarrow$ Wholesalers $\rightarrow$ Retailers $\rightarrow$ Consumer

Channel IV: Farmers $\rightarrow$ Processor $\rightarrow$ Consumer

Channel V: Farmers $\rightarrow$ Consumer

Table 9: Wheat seed marketing channels

\begin{tabular}{llll}
\hline Marketing Channels & Overall & Formal System & Informal System \\
\hline Channel I & $8.61 \%$ & $3.33 \%$ & $15.79 \%$ \\
Channel II & $16.33 \%$ & $20 \%$ & $10.53 \%$ \\
Channel III & $51.02 \%$ & $56.67 \%$ & $42.11 \%$ \\
Channel IV & $4.08 \%$ & $3.33 \%$ & $5.26 \%$ \\
Channel V & $20.41 \%$ & $16.67 \%$ & $26.32 \%$ \\
\hline
\end{tabular}

Source: Field survey 2020 
Table 10: Satisfaction from wheat seed production

\begin{tabular}{llll}
\hline Variable & Overall & Formal system & Informal system \\
\hline Strongly satisfied & $5 \%$ & $0 \%$ & $10 \%$ \\
Moderately satisfied & $68.33 \%$ & $73.33 \%$ & $63.33 \%$ \\
Undecided & $10 \%$ & $16.67 \%$ & $3.33 \%$ \\
Moderately unsatisfied & $15 \%$ & $10 \%$ & $20 \%$ \\
Strongly unsatisfied & $1.67 \%$ & $0 \%$ & $3.33 \%$ \\
\hline
\end{tabular}

Source: Field survey 2020

Table 11: Seed production constraints

\begin{tabular}{lcccccc}
\hline \multicolumn{1}{c}{ Constraints } & \multicolumn{2}{c}{ Formal seed producers } & \multicolumn{2}{c}{ Informal seed producers } & \multicolumn{2}{c}{ Overall } \\
\cline { 2 - 7 } & RII & Rank & RII & Rank & RII & Rank \\
\hline Disease/Insect & 0.65 & III & 0.56 & IV & 0.60 & IV \\
Scarcity of irrigation & 0.6 & IV & 0.64 & II & 0.62 & III \\
water & & & & & & \\
Lack of quality input & 0.67 & II & 0.73 & I & 0.7 & I \\
Natural hazards & 0.69 & I & 0.59 & III & 0.64 & II \\
Others(weeding) & 0.39 & V & 0.48 & V & 0.44 & V \\
\hline
\end{tabular}

Source: Field survey 2020

Table 12: Marketing constraints

\begin{tabular}{llccccc}
\hline \multicolumn{1}{c}{ Constraints } & \multicolumn{2}{c}{ Formal seed producer } & \multicolumn{2}{c}{ Informal seed producers } & \multicolumn{2}{c}{ overall } \\
\cline { 2 - 7 } & RII & Rank & RII & Rank & RII & Rank \\
\hline Access to market & 0.74 & II & 0.8 & I & 0.76 & I \\
Access to input & 0.63 & III & 0.55 & III & 0.61 & III \\
supply & & & & & & \\
Technical support & 0.75 & I & 0.73 & II & 0.74 & II \\
Work schedule & 0.45 & IV & 0.53 & IV & 0.47 & IV \\
Illiteracy & 0.43 & V & 0.4 & V & 0.42 & V \\
\hline Source: Field survey 2020 & & & & & &
\end{tabular}

Most of the seed producers were moderately satisfied with the return of wheat seed production. This indicates wheat seed production is a satisfactory enterprise (Table 10).

\section{Wheat Seed Production Related Constraints}

The study showed that seed production is economically viable agribusiness. But problems like lack of quality inputs, irrigation, natural hazards etc. were found prevailing in the study area lowering return from production process. While analyzing problems of formal seed producers, erratic winter rainfall was found as a major constraint ( $\mathrm{RII}=0.69$ ). Lack of quality inputs like seed and fertilizers was second major problem followed by disease/insects, scarcity of irrigation water and weeding with RII of $0.67,0.65,0.6$ and 0.39 respectively (Table 11 ).

For informal seed producers lack of quality input like seed was found as major constraint $(\mathrm{RII}=0.7)$ followed by erratic winter rainfall, scarcity of irrigation water, disease/insect, and weeding (Table 11).

In overall lack of quality input was found to be major constraint in seed production process. Similarly, erratic winter rainfall caused stress during plant development period and hampered the harvesting. Cost of irrigation was found high (NRs. 400/hour) in the study area, resulting in scarcity of irrigation water as a constraint. Similarly, lack of market information and access to market was found to be major seed marketing constraint (Table 12).

\section{Conclusion}

In overall the major wheat seed production constraints are lack of quality input and natural hazards while major marketing constraints are low access to market and lack of technical support. Since agriculture is the primary source of household income in the study area, income can be increased by increasing value of farm produced seed. Wheat seed producers are not provided services such as field inspection, seed processing and certification which can potentially increase per unit price received by farmers. Similarly, number of middlemen involved in seed marketing channel is high.

\section{References}

Elgilany A, Sulaiman J, and Mohd S (2011, March 11) Wheat Production and Economics . American Journal of Agricultural and Biological Science, 6(3), 332-338. doi:10.3844/ajabssp.2011.332.338

Heena (2016) An Economic Analysis of Input Use in Wheat Crop in Haryana. Krishikosh Institutional Repository. Retrieved from http://krishikosh.egranth.ac.in/displaybitstream?handle $=1 / 5810014461$ 
JICA (2017) Wheat Seed Production Techniques.

Nickerson J (2020). Seed System Definitions. Retrieved from Agrilinks: https://www.agrilinks.org/post/seed-systemdefinitions

NPHC (2011) National Population and Housing Census 2011. kathmandu,Nepal: Government of Nepal National Planning Commission Secretariat Central Bureau of Statistics.
NSB (2013) National Seed Vision 2013 - 2025. Government of Nepal Ministry of Agricultural Development National Seed Board National Seed Board Hariharbhawan, Lalitpur, Nepal, 140.

Thapa B (2005) Vigour Test Methods and Accelerated Ageing Test. A term paper presented in Institute of Agriculture and Animal Science (IAAS), Rampur, Chitawan. Retrieved August 23, 2005 